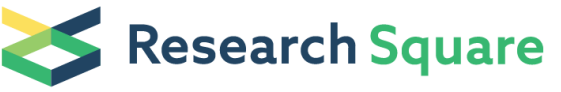 \\ Preprints are preliminary reports that have not undergone peer review. \\ They should not be considered conclusive, used to inform clinical practice, or referenced by the media as validated information.
}

\section{Expression of Wnt10b, $\beta$-catenin, Rankl and Runx2 in the Periodontal Tissues During Orthodontic Tooth Movement in Rats}

\section{He Wang}

First Affiliated Hospital of Harbin Medical University

\section{SiYan Chen}

First Affiliated Hospital of Harbin Medical University

Miaomiao Zhang ( $\sim$ zhangmiaohlj@163.com )

Harbin Medical University

Kaixin Ji

First Affiliated Hospital of Harbin Medical University

Minjie Zhang

First Affiliated Hospital of Harbin Medical University

\section{Man Zhang}

First Affiliated Hospital of Harbin Medical University

Yi Li

First Affiliated Hospital of Harbin Medical University

Yanyun Zhang

First Affiliated Hospital of Harbin Medical University

\section{Research}

Keywords: Wnt10b, Rankl, $\beta$-catenin, Runx2, periodontal tissue remodeling, orthodontic tooth movement

Posted Date: June 9th, 2021

DOI: https://doi.org/10.21203/rs.3.rs-585059/v1

License: (c) (i) This work is licensed under a Creative Commons Attribution 4.0 International License. Read Full License 


\section{Abstract}

Objective

to investigate the expression of Wnt10b, Rankl, $\beta$-catenin and Runx2 mRNA in periodontal tissues during orthodontic tooth movement (OTM) in rats;

Materials and methods

36 healthy male SD rats were selected and divided into six groups randomly according to the time of the force applied (0 hour, 12 hours, 24 hours, 5 days, 7 days, 14 days), with 6 rats in each group. Ohour group served as the control group. Except for control group, an orthodontic force of $50 \mathrm{~g}$ was applied to the upper-left first molar with a nickeltitanium tension spring. The expression of Wnt10b, Rankl, $\beta$-catenin and Runx2 during OTM were detected by Realtime PCR (RT-PCR).

Results

Compared with the control group, Wnt10b mRNA expression in the pressure side was inhibited at the initial stage, and then increased, reached peak at day 5. A strong expression of Rankl mRNA in the pressure side can be seen from 12 hours to 14 days. The expression level was consistently higher than control group, and it peaked at day 7 . The initial expression of $\beta$-catenin and Runx 2 mRNA in the periodontal tissues of the experimental groups were small in the tension side, but still higher than the control group. The expression increased gradually with the extension of time, and reached the peak at day 7 after force treatment.

Conclusion

Wnt10b, $\beta$-catenin, Rankl and Runx2 are related to periodontal tissues remodeling during OTM in rats; Wnt10b/ $\beta$ catenin signaling pathways participate in periodontal tissue remodeling during OTM.

\section{Introduction}

OTM is achieved by applying suitable mechanical force to periodontal tissue to make it reconstruct. Orthodontic force causes local stress changes in periodontal tissue, cell deformation and the release of a variety of cytokines, chemokines and inflammatory factor, such as interleukin-1 beta (IL-1 beta), tumor necrosis factor alpha (TNF), receptor activator of nuclear factor kappa B ligand (Rankl), Runx2 and so on[1, 2]. These factors were found to play a major role in bone reconstruction[3]. Moreover, interaction between osteoblast and osteoclast in periodontal tissue causes alveolar bone absorption on pressure side and bone formation on tension side[4,5]. Wnt/ $\beta$-catenin pathways were involved in osteoblasts differentiation and bone formation[6]. In recent years, studies found that the classic Wnt/ $\beta$-catenin signaling pathways were involved in regulating the physiological metabolism of periodontal membrane[7]. Wnt/ $\beta$-catenin signaling pathway in the periodontal ligament fibroblasts can be activated[8]. As an important factor in Wnt signaling pathways, $\beta$-catenin plays an important role in the early stages of teeth formation[9]. Kuniaki pointed out that in osteoclast, transforming growth factor- $\beta 1$ (TGF - $\beta 1$ ) can stimulate the generation and maturation of wnt10b, and then promote the osteoblast mineralization[10]. Research reports that the overexpression of $\beta$-catenin in WNT signaling pathways will inhibits Rankl expression and then affect the osteoclast activity[11]. However, it is still not clear that the influence on periodontal tissue reconstruction of pressure side by classic WNT signaling pathways under orthodontic force. Runx2 functions as an osteogenic differentiation factor in bone cells. As a control factor in the early stages of osteoblast formation, Runx2 participates in the skull reconstruction, teeth formation, cartilage formation, and angiogenesis[12]. OTM mechanism is unclear. Though the establishment of animal model of OTM, 
using RT-PCR to detect wnt10b and Rankl expression in periodontal tissue of pressure side, $\beta$-catenin and Runx 2 expression in periodontal tissue of tension side at different time point, this study aims to preliminarily discuss whether Wnt/ß-catenin signaling pathways are involved in periodontal tissue reconstruction during OTM.

\section{Materials And Methods}

\section{Establishment of orthodontic tooth movement model in rats}

36 healthy adult male SD rats (provided by the Animal Experimental Center of Harbin Medical University) with body mass $(190 \pm 20) \mathrm{g}$ were selected. According to different loading time, they were randomly designed to 6 groups (0 hour, 12 hours, 24 hours, 5 days, 7 days, 14 days), with 6 rats in each group.0hour group acted as control group, which were not subjected to mechanical stress. Adaptive feeding is applied for 1 week before experiment. This experiment was approved by the Ethics Committee of Harbin Medical University.

The rats were anesthetized by intraperitoneal injection of chloral hydrates $(10 \%, 3 \mathrm{ml} / \mathrm{kg})$. Except for control group, the nickel-titanium tension spring was ligated to the upper-left first molar and central incisors with ligation wire $(0.08 \mathrm{~mm}$ in diameter and $9 \mathrm{~mm}$ in length) to generate $50 \mathrm{~g}$ force to move the first molar in the mesial direction. Grind a groove of about $0.5 \mathrm{~mm}$ at the cervical margin of the central incisors, fix the ligation wire on the central incisors with fluid resin to prevent it from falling off, and complete the rat OTM model (Fig. 1).

\section{Periodontal tissue acquisition and RT-PCR experiment}

Animals in each group were sacrificed separately after 0 hour, 12 hours, 24 hours, 5 days, 7 days and 14 days of force application, and the maxillae were separated. $2 \mathrm{~mm}$ wide periodontal tissues were taken from the pressure area and tension area respectively, weighing about $100 \mathrm{mg}$, and then grind the periodontal tissues in liquid nitrogen. Total RNA of samples was extracted by using TriZol Total RNA Isolation Reagent (Life Technologies BRL) according to the manufacturer's instructions. Ultraviolet spectrophotometer was used to detect the concentration and purity of RNA. Reverse transcription was performed according to 1000ng mRNA in each reaction system, which consists of 20ul stuff. The first strand of Complementary DNA (cDNA) (TAKARA kit) is synthesized and stored at $-20^{\circ} \mathrm{C}$.

ABI 7500 Fast Real-Time PCR system is as follows: SYBR Premix Ex Taq II 10ul,0.8ul for each primer[cDNA template 2ulaROX Reference Dye II $0.4 \mathrm{ul} \mathrm{dH}_{2} \mathrm{O}$ 6u, totally $20 \mathrm{ul}$. Every sample is provided with three auxiliary holes, with $\beta$-actin as internal reference. The expression of Wnt10b, $\beta$-catenin, Rankl and Runx 2 were detected with the Ohour group as the control group. The primers were synthesized by Sangon Biotech(shanghai), and the primer sequences were as follows (Table 1 and Table 2).

\section{Results}

Statistical analysis is performed by using SPSS 17.0 software, all data are presented as mean \pm standard deviation, P $<0.05$ was statistically significant.

\section{Expression of Wnt10b mRNA in the pressure side of periodontal tissue}

Compared with the control group, the expression level of wnt10b mRNA was inhibited at the primary stage, increased after 24 hours, reached the peak at day 5, then decreased to the normal level at day 14 (Fig. 2). 
Compared with the control group, the expression level of Rankl mRNA in experimental groups was higher and gradually increased with the extension of the loading time $(P<0.05)$, reached the peak at day 7 , and decreased to the normal level at day 14(Fig. 3).

\section{Expression of $\beta$-catenin mRNA in the tension side of periodontal tissue}

Compared with the control group, the expression amount of $\beta$-catenin mRNA increased after the force treatment $(P<$ 0.05). The expression showed a gradual upward trend with the extension of loading time, and reached the peak value at day 7 after loading, decreased after 14 days $(P<0.05)$ (Fig. 4).

\section{Expression of Runx2 mRNA in the tension side of periodontal tissue}

Compared with the control group, the expression level of Runx2 mRNA increased after applying force $(P<0.05)$. The expression level of Runx2 mRNA showed an upward trend with the extension of the loading time, which increased slowly at the beginning, reached the highest level at day 7 after loading, and decreased after 14 days. Compared with the control group, there were statistically significant differences at all time points except for day $14(P<0.05)(F i g$. 5).

\section{Discussion}

During OTM, when appropriate orthodontic force is applied, the osteoclast activity in the pressure area of the periodontal tissue is enhanced, the osteogenesis activity in the tension area increased, and the periodontal tissue reconstruction is active[13]. Wnt/ $\beta$-catenin classical signaling pathway and Rankl/Rank/OPG system are indispensable for osteoblast differentiation and maturation[14]. RANKL is one of the family members in RANKL/RANK/OPG system. It is a key cytokine that regulates osteoclast differentiation and bone resorption by binding to receptor activator of nuclear factor-KB (RANK) and sending signals from cytoplasm to nucleus[15]. Patricia et al. confirmed that RANK positive staining cells were pre-osteoclasts at the initial stage of OTM, and RANKL promoted the maturation and fusion of pre-osteoclasts into activated osteoclasts[16].Studies have demonstrated that the expression of RANKL mRNA increased in compression side as a consequence of application of orthodontic force[17]. In this experiment, compared with the control group, the expression level of Rankl mRNA in the pressure side increased with the extension of the time of force treatment, and reached its peak at day 7 after force treatment. The expression decreased but was still higher than that in the control group after 14 days of force treatment. The results are consistent with previous studies.

Runx2, also known as core binding factor A1 (Cbfa1), is an important transcription factor in bone formation and plays an pivotal role in bone formation, cartilage formation, and bone metabolism-related diseases[18]. Experiments show that in Runx2-deficient mice, the formation of intramembranous and cartilage bone were completely interrupted, and finally the bone and cartilage-like bone were completely lost[19]. Runx2 gene mutation will lead to Cleidocranial dysplasia (CCD)[12]. W et al. showed that Runx2 promoted osteoblast differentiation in periodontal tissues of tension side during the initial stage of rat tooth movement[20].Study has shown that it had a significantly higher Runx2 mRNA after being loaded with mechanical stress in osteoblasts.[21] Similar to the results of the study, the expression of Runx2 in the tension side presented to be higher in experimental groups compared with the control group, and peaked at day 7 and began to decline after 14 days in this experiment.

The Wnt pathways include the classical Wnt / $\beta$-catenin signaling pathway, planar polar cell pathway, Wnt /Ca2 + pathway, and intracellular pathways that regulate spindle orientation and asymmetric cell division. Wnt protein is concentrated in the areas with more active differentiation in embryonic tissue, such as periodontal membrane of incisor and the cement-periodontal membrane interface[22]. Wnt/ $\beta$-catenin classical signaling pathways expressed at 
different stages of osteoblast differentiation. When classical pathways are inhibited, osteogenesis imperfectness and osteoporosis will occur in the early stages of osteoblast differentiation[23, 24]. R et al. also found that Wnt/ $\beta$-catenin signaling pathway can promote bone repair of injured growth plate. Inhibition of $\beta$-catenin with $\beta$-catenin inhibitor can lead to reduced bone formation, but can promote the formation of cartilage in injure repair areas through animal experiments[25]. C et al. showed that Wnt10b-/- mice showed reduced bone trabecular formation, and confirmed that Wnt10b promoted bone formation by affecting the differentiation of mesenchymal cells, which was considered as an important endogenous factor regulating bone formation[26]. P et al. demonstrated that mechanical loading could stimulate the transient accumulation of dephosphorylated $\beta$-catenin in the cytoplasm and it translocated into the nucleus through the cellular experiment in vitro, which suggested that mechanical force stimulation to the periodontal membrane cells could activate the expression of $\beta$-catenin[8]. Juan Lu et al. found that DKK1, Wnt3a, Wnt10b and $\beta$ catenin were involved in periodontal tissue remodeling during OTM in rats by immunohistochemistry[27]. In this experiment, it was found by RT- PCR method that Wnt10b mRNA expression tended to be weak at the pressure side in the initial stage of mechanical loading, and after 24 hours, the expression first increased, reached its peak at day 5 and then decreased, returned to the normal level at day 14 after force loading. This result is similar to the expression trend of Rankl mRNA, which indicated that 5-7 days after force treatment is the most active period of bone remodeling, and Wnt10b is an important factor involved in osteoblast differentiation in the classical signaling pathway. This result suggests that the Wnt classical signaling pathway is involved in the reconstruction of periodontal tissues on the pressure side, and there is a tendency of mesenchymal cell differentiation and bone formation during the active period of bone reconstruction. On the tension side, the expression of $\beta$-catenin mRNA increased gradually with the extension of loading time and reached the maximum at day 7 . These changes were consistent with our previous experimental results and were similar to the expression trend of Runx2 mRNA, which indicated that bone remodeling was most active during 5-7 days of mechanical loading. In this experiment, the relative quantitative data of Wnt10b, $\beta$-catenin, Rankl and Runx2 mRNA were analyzed. It was found that the expression changes trend of wnt10b and Rankl mRNA on the pressure side were closely related in different periods, and both of the expression of $\beta$-catenin and Runx 2 mRNA on the tension side gradually increased in parallel with time of mechanical stress.

\section{Conclusion}

Wnt10b, $\beta$-catenin, Rankl and Runx2 are expressed when appropriate orthodontic force is applied to periodontal tissue. Wnt/ $\beta$-catenin signaling pathway might play a pivotal role in periodontal tissue remodeling.

\section{Declarations}

\section{Ethics approval and consent to participate}

This study was approved by Ethics Committee of Harbin Medical University.

\section{Consent for publication}

Not applicable.

\section{Competing interests}

The authors declare no potential conflicts of interest.

\section{Availability of data and material}


All data generated or analyzed during the current study are included in this article.

\section{Funding}

This study was supported by Research and Innovation Fund of First Affiliated Hospital of Harbin Medical University.

\section{Authors information}

Affiliations

Department of Orthodontics, School of stomatology, Harbin Medical University, Harbin, 150001, PR China He Wang, SiYan Chen, Miaomiao Zhang, Kaixin Ji, Minjie Zhang, Man Zhang, Yi Li, Yanyun Zhang.

Authors' contributions 


\begin{tabular}{|c|c|c|c|c|c|c|}
\hline \multirow{2}{*}{$\begin{array}{l}\text { Author(First } \\
\text { name, Last } \\
\text { name) }\end{array}$} & \multicolumn{2}{|c|}{ Criteria 1(and/or) } & \multicolumn{2}{|c|}{ Criteria 2(and/or) } & \multirow{2}{*}{$\begin{array}{l}\text { Criteria } \\
\mathbf{3} \\
\text { Gave } \\
\text { final } \\
\text { approval }\end{array}$} & \multirow[b]{2}{*}{$\begin{array}{l}\text { Criteria } 4 \\
\text { Agree to be } \\
\text { accountable } \\
\text { for all } \\
\text { aspects of } \\
\text { the work in } \\
\text { ensuring that } \\
\text { questions } \\
\text { relating to } \\
\text { the accuracy } \\
\text { or integrity } \\
\text { of any part } \\
\text { of the work } \\
\text { are } \\
\text { appropriately } \\
\text { investigated } \\
\text { and } \\
\text { resolved }\end{array}$} \\
\hline & $\begin{array}{l}\text { Substantially } \\
\text { contributed } \\
\text { to } \\
\text { conception } \\
\text { or design }\end{array}$ & $\begin{array}{l}\text { contributed to } \\
\text { acquisition,analysis,or } \\
\text { interpretation of data }\end{array}$ & $\begin{array}{l}\text { drafted the } \\
\text { manuscript }\end{array}$ & $\begin{array}{l}\text { critically } \\
\text { revised the } \\
\text { manuscript } \\
\text { for } \\
\text { important } \\
\text { intellectual } \\
\text { content }\end{array}$ & & \\
\hline He Wang & $\begin{array}{l}\text { contributed } \\
\text { to } \\
\text { conception } \\
\text { and design }\end{array}$ & $\begin{array}{l}\text { contributed to } \\
\text { acquisition,analysis,and } \\
\text { interpretation of data }\end{array}$ & $\begin{array}{l}\text { drafted } \\
\text { manuscript }\end{array}$ & $\begin{array}{l}\text { critically } \\
\text { revised the } \\
\text { manuscript }\end{array}$ & $\begin{array}{l}\text { Gave } \\
\text { final } \\
\text { approval }\end{array}$ & $\begin{array}{l}\text { agrees to be } \\
\text { accountable } \\
\text { for all } \\
\text { aspects of } \\
\text { the work } \\
\text { ensuring } \\
\text { accuracy } \\
\text { and integrity }\end{array}$ \\
\hline Siyan Chen & $\begin{array}{l}\text { contributed } \\
\text { to } \\
\text { conception }\end{array}$ & $\begin{array}{l}\text { contributed to } \\
\text { acquisition }\end{array}$ & $\begin{array}{l}\text { drafted } \\
\text { manuscript }\end{array}$ & $\begin{array}{l}\text { critically } \\
\text { revised the } \\
\text { manuscript }\end{array}$ & $\begin{array}{l}\text { Gave } \\
\text { final } \\
\text { approval }\end{array}$ & $\begin{array}{l}\text { agrees to be } \\
\text { accountable } \\
\text { for all } \\
\text { aspects of } \\
\text { the work } \\
\text { ensuring } \\
\text { accuracy } \\
\text { and integrity }\end{array}$ \\
\hline Kaixin Ji & $\begin{array}{l}\text { contributed } \\
\text { to design }\end{array}$ & $\begin{array}{l}\text { contributed to } \\
\text { acquisition }\end{array}$ & $\begin{array}{l}\text { drafted } \\
\text { manuscript }\end{array}$ & $\begin{array}{l}\text { critically } \\
\text { revised the } \\
\text { manuscript }\end{array}$ & $\begin{array}{l}\text { Gave } \\
\text { final } \\
\text { approval }\end{array}$ & $\begin{array}{l}\text { agrees to be } \\
\text { accountable } \\
\text { for all } \\
\text { aspects of } \\
\text { the work } \\
\text { ensuring } \\
\text { accuracy } \\
\text { and integrity }\end{array}$ \\
\hline $\begin{array}{l}\text { Minjie } \\
\text { Zhang }\end{array}$ & $\begin{array}{l}\text { contributed } \\
\text { to design }\end{array}$ & $\begin{array}{l}\text { contributed to } \\
\text { acquisition and } \\
\text { analysis }\end{array}$ & $\begin{array}{l}\text { drafted } \\
\text { manuscript }\end{array}$ & $\begin{array}{l}\text { critically } \\
\text { revised the } \\
\text { manuscript }\end{array}$ & $\begin{array}{l}\text { Gave } \\
\text { final } \\
\text { approval }\end{array}$ & $\begin{array}{l}\text { agrees to be } \\
\text { accountable } \\
\text { for all } \\
\text { aspects of } \\
\text { the work } \\
\text { ensuring } \\
\text { accuracy } \\
\text { and integrity }\end{array}$ \\
\hline Man Zhang & $\begin{array}{l}\text { contributed } \\
\text { to design }\end{array}$ & $\begin{array}{l}\text { contributed to } \\
\text { acquisition }\end{array}$ & $\begin{array}{l}\text { drafted } \\
\text { manuscript }\end{array}$ & $\begin{array}{l}\text { critically } \\
\text { revised the } \\
\text { manuscript }\end{array}$ & $\begin{array}{l}\text { Gave } \\
\text { final } \\
\text { approval }\end{array}$ & $\begin{array}{l}\text { agree to be } \\
\text { accountable } \\
\text { for all } \\
\text { aspects of } \\
\text { the work } \\
\text { ensuring } \\
\text { accuracy } \\
\text { and integrity }\end{array}$ \\
\hline
\end{tabular}




\begin{tabular}{|c|c|c|c|c|c|c|}
\hline Yi Li & $\begin{array}{l}\text { contributed } \\
\text { to design }\end{array}$ & $\begin{array}{l}\text { contributed to } \\
\text { acquisition }\end{array}$ & $\begin{array}{l}\text { drafted } \\
\text { manuscript }\end{array}$ & $\begin{array}{l}\text { critically } \\
\text { revised the } \\
\text { manuscript }\end{array}$ & $\begin{array}{l}\text { Gave } \\
\text { final } \\
\text { approval }\end{array}$ & $\begin{array}{l}\text { agrees to be } \\
\text { accountable } \\
\text { for all } \\
\text { aspects of } \\
\text { the work } \\
\text { ensuring } \\
\text { accuracy } \\
\text { and integrity }\end{array}$ \\
\hline $\begin{array}{l}\text { Yanyun } \\
\text { Zhang }\end{array}$ & $\begin{array}{l}\text { contributed } \\
\text { to design }\end{array}$ & contributed to analysis & $\begin{array}{l}\text { drafted } \\
\text { manuscript }\end{array}$ & $\begin{array}{l}\text { critically } \\
\text { revised the } \\
\text { manuscript }\end{array}$ & $\begin{array}{l}\text { Gave } \\
\text { final } \\
\text { approval }\end{array}$ & $\begin{array}{l}\text { agrees to be } \\
\text { accountable } \\
\text { for all } \\
\text { aspects of } \\
\text { the work } \\
\text { ensuring } \\
\text { accuracy } \\
\text { and integrity }\end{array}$ \\
\hline $\begin{array}{l}\text { Miaomiao } \\
\text { Zhang }\end{array}$ & $\begin{array}{l}\text { contributed } \\
\text { to } \\
\text { conception } \\
\text { and design }\end{array}$ & $\begin{array}{l}\text { contributed to } \\
\text { acquisition, analysis, } \\
\text { and interpretation }\end{array}$ & $\begin{array}{l}\text { drafted } \\
\text { manuscript }\end{array}$ & $\begin{array}{l}\text { critically } \\
\text { revised the } \\
\text { manuscript }\end{array}$ & $\begin{array}{l}\text { Gave } \\
\text { final } \\
\text { approval }\end{array}$ & $\begin{array}{l}\text { agrees to be } \\
\text { accountable } \\
\text { for all } \\
\text { aspects of } \\
\text { the work } \\
\text { ensuring } \\
\text { accuracy } \\
\text { and integrity }\end{array}$ \\
\hline
\end{tabular}

\section{Acknowledgements}

Thanks to all the members who have provided excellent samples, materials and tools.

\section{References}

[1] Henneman S, Von den Hoff JW, Maltha JC. Mechanobiology of tooth movement. Eur J Orthod 2008;30:299-306.

[2] Kitaura H, Kimura K, Ishida M, Sugisawa H, Kohara H, Yoshimatsu M, et al. Effect of cytokines on osteoclast formation and bone resorption during mechanical force loading of the periodontal membrane. ScientificWorldJournal 2014;2014:617032.

[3] Nimeri G, Kau CH, Abou-Kheir NS, Corona R. Acceleration of tooth movement during orthodontic treatment-a frontier in orthodontics. Prog Orthod 2013;14:42.

[4] Gama SK, Habib FA, Monteiro JS, Paraguassu GM, Araujo TM, Cangussu MC, et al. Tooth movement after infrared laser phototherapy: clinical study in rodents. Photomed Laser Surg 2010;28 Suppl 2:S79-83.

[5] Chen X, Wang Z, Duan N, Zhu G, Schwarz EM, Xie C. Osteoblast-osteoclast interactions. Connective Tissue Research 2017;59:99-107.

[6] Wang PP, Zhu XF, Yang L, Liang H, Feng SW, Zhang RH. Puerarin stimulates osteoblasts differentiation and bone formation through estrogen receptor, p38 MAPK, and Wnt/ $\beta$-catenin pathways. J Asian Nat Prod Res 2012;14:897905.

[7] Lim WH, Liu B, Cheng D, Williams BO, Mah SJ, Helms JA. Wnt signaling regulates homeostasis of the periodontal ligament. J Periodontal Res 2014;49:751-9. 
[8] Premaraj S, Souza I, Premaraj T. Mechanical loading activates beta-catenin signaling in periodontal ligament cells. Angle Orthod 2011;81:592-9.

[9] Chen J, Lan Y, Baek JA, Gao Y, Jiang R. Wnt/beta-catenin signaling plays an essential role in activation of odontogenic mesenchyme during early tooth development. Dev Biol 2009;334:174-85.

[10] Ota K, Quint P, Ruan M, Pederson L, Westendorf JJ, Khosla S, et al. TGF-beta induces Wnt10b in osteoclasts from female mice to enhance coupling to osteoblasts. Endocrinology 2013;154:3745-52.

[11] Kovacs B, Vajda E, Nagy EE. Regulatory Effects and Interactions of the Wnt and OPG-RANKL-RANK Signaling at the Bone-Cartilage Interface in Osteoarthritis. Int J Mol Sci 2019;20.

[12] Vimalraj S, Arumugam B, Miranda PJ, Selvamurugan N. Runx2: Structure, function, and phosphorylation in osteoblast differentiation. Int J Biol Macromol 2015;78:202-8.

[13] Misawa-Kageyama Y, Kageyama T, Moriyama K, Kurihara S, Yagasaki H, Deguchi T, et al. Histomorphometric study on the effects of age on orthodontic tooth movement and alveolar bone turnover in rats. Eur J Oral Sci 2007; 115:124-30.

[14] Kenkre JS, Bassett J. The bone remodelling cycle. Ann Clin Biochem 2018;55:308-27.

[15] Tudpor K, van der Eerden BC, Jongwattanapisan P, Roelofs JJ, van Leeuwen JP, Bindels RJ, et al. Thrombin receptor deficiency leads to a high bone mass phenotype by decreasing the RANKL/OPG ratio. Bone 2015;72:14-22.

[16] Brooks P, Nilforoushan D, Manolson M, Simmons C, Gong S. Molecular markers of early orthodontic tooth movement. The Angle orthodontist 2009;79:1108-13.

[17] Otero L, García DA, Wilches-Buitrago L. Expression and Presence of OPG and RANKL mRNA and Protein in Human Periodontal Ligament with Orthodontic Force. Gene Regul Syst Bio 2016;10:15-20.

[18] Komori T. Runx2, an inducer of osteoblast and chondrocyte differentiation. Histochem Cell Biol 2018;149:313-23.

[19] Maeno T, Moriishi T, Yoshida CA, Komori H, Kanatani N, Izumi S, et al. Early onset of Runx2 expression caused craniosynostosis, ectopic bone formation, and limb defects. Bone 2011;49:673-82.

[20] Watanabe T, Nakano N, Muraoka R, Shimizu T, Okafuji N, Kurihara S, et al. Role of Msx2 as a promoting factor for Runx2 at the periodontal tension sides elicited by mechanical stress. Eur J Med Res 2008;13:425-31.

[21] Yanagisawa M, Suzuki N, Mitsui N, Koyama Y, Otsuka K, Shimizu N. Compressive force stimulates the expression of osteogenesis-related transcription factors in ROS 17/2.8 cells. Arch Oral Biol 2008;53:214-9.

[22] Boyle W, Simonet W, Lacey D. Osteoclast differentiation and activation. Nature 2003;423:337-42.

[23] Holmen SL, Zylstra CR, Mukherjee A, Sigler RE, Faugere MC, Bouxsein ML, et al. Essential role of beta-catenin in postnatal bone acquisition. J Biol Chem 2005;280:21162-8.

[24] Glass DA, 2nd, Bialek P, Ahn JD, Starbuck M, Patel MS, Clevers H, et al. Canonical Wnt signaling in differentiated osteoblasts controls osteoclast differentiation. Dev Cell 2005;8:751-64. 
[25] Chung R, Wong D, Macsai C, Piergentili A, Del Bello F, Quaglia W, et al. Roles of Wnt/beta-catenin signalling pathway in the bony repair of injured growth plate cartilage in young rats. Bone 2013;52:651-8.

[26] Belaya Z, Grebennikova T, Melnichenko G, Nikitin A, Solodovnikov A, Brovkina O, et al. Effects of endogenous hypercortisolism on bone mRNA and microRNA expression in humans. Osteoporosis international : a journal established as result of cooperation between the European Foundation for Osteoporosis and the National Osteoporosis Foundation of the USA 2018;29:211-21.

[27] Lu J, Duan Y, Zhang M, Wu M, Wang Y. Expression of Wnt3a, Wnt10b, beta-catenin and DKK1 in periodontium during orthodontic tooth movement in rats. Acta Odontol Scand 2016;74:217-23.

\section{Tables}

Table 1: Pressure side

\begin{tabular}{|cr|}
\hline \multicolumn{2}{|c|}{ primer sequence } \\
\hline RANKL sense primer & 5-AGGCTGGGCCAAGATCTCT-3' \\
antisense primer & 5-GATAGTCCGCAGGTACGCT-3' \\
Wnt10b sense primer & 5-TCAGGCTCTTAGGGAGGCT-3' \\
antisense primer & 5-ATTATCCATTCCCACCCGCC-3' \\
B-actin sense primer & 5-CACCCGCGAGTACAACCTT-3' \\
antisense primer & 5-CCCATACCCACCATCACACC-3' \\
\hline
\end{tabular}

Table 2: Tension side

\begin{tabular}{|c|c|c|}
\hline \multicolumn{3}{|c|}{ primer sequence } \\
\hline \multirow[t]{2}{*}{ RUNX2 } & sense primer & 5'-CGCCTCACAAACAACCACAG-3' \\
\hline & tisense primer & 5'AATGACTCGGTTGGTCTCGG-3' \\
\hline \multirow[t]{2}{*}{$\beta$-catenin } & sense primer & 5'-ATCATTCTGGCCAGTGGTGG-3' \\
\hline & tisense primer & 5'-GACAGCACCTTCAGCACTCT-3' \\
\hline \multirow[t]{2}{*}{$\beta$-actin } & sense primer & 5'-TCAGGTCATCACTATCGGCAAT-3' \\
\hline & tisense primer & 5'-AAAGAAAGGGTGTAAAACGCA-3 \\
\hline
\end{tabular}

\section{Figures}




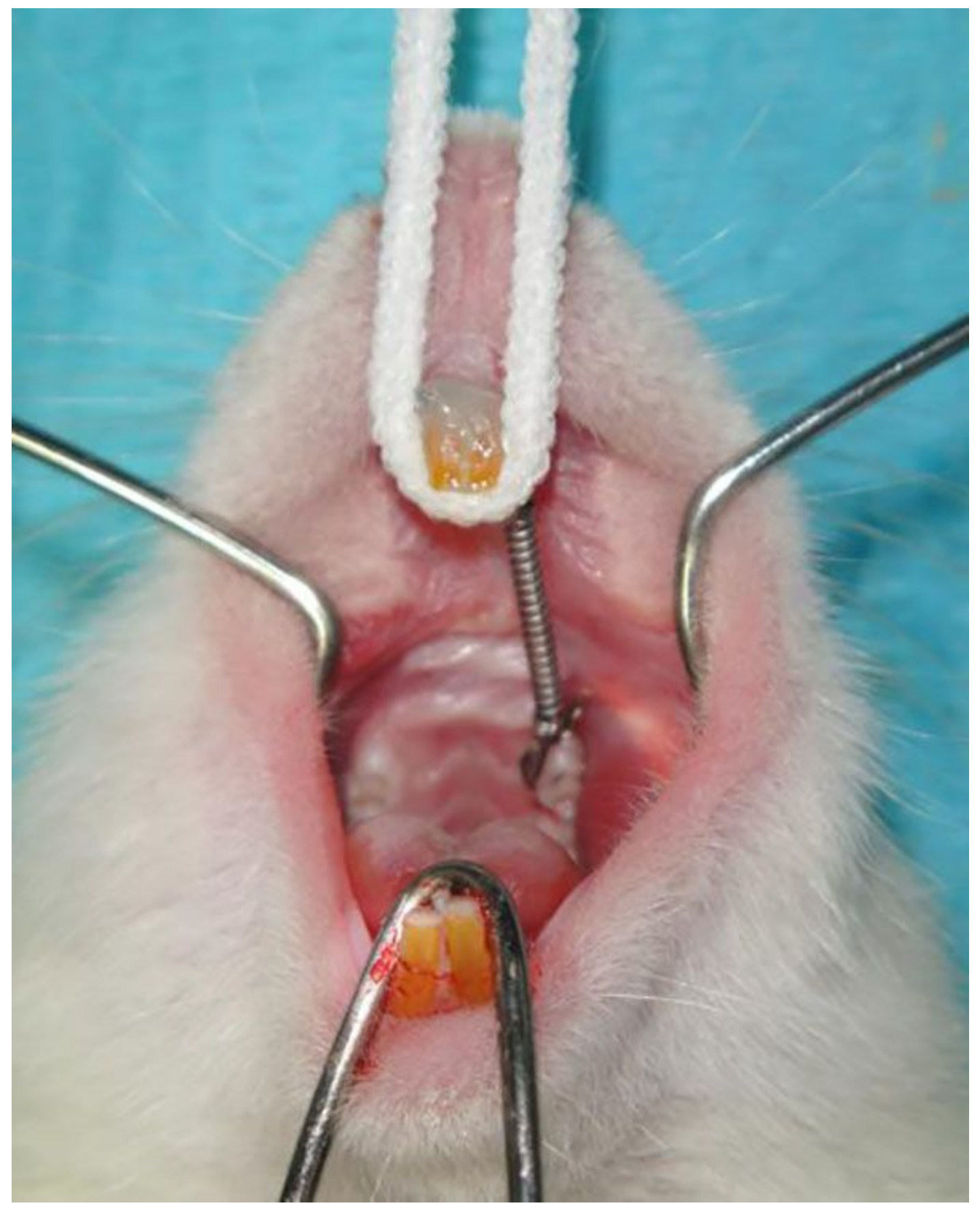

\section{Figure 1}

Establishment of orthodontic tooth movement model in rats. The rats were anesthetized by intraperitoneal injection of chloral hydrates $(10 \%, 3 \mathrm{ml} / \mathrm{kg})$. The limbs of the rats were extended and tied to the board. The mouth of the rats was propped open with a self-made mouth opener. the nickel-titanium tension spring was ligated to the left maxillary first molar and central incisors with ligation wire to generate $50 \mathrm{~g}$ force to move the first molar in the mesial direction. Grind a groove of about $0.5 \mathrm{~mm}$ at the cervical margin of the central incisors, fix the ligation wire on the central incisors with fluid resin. 


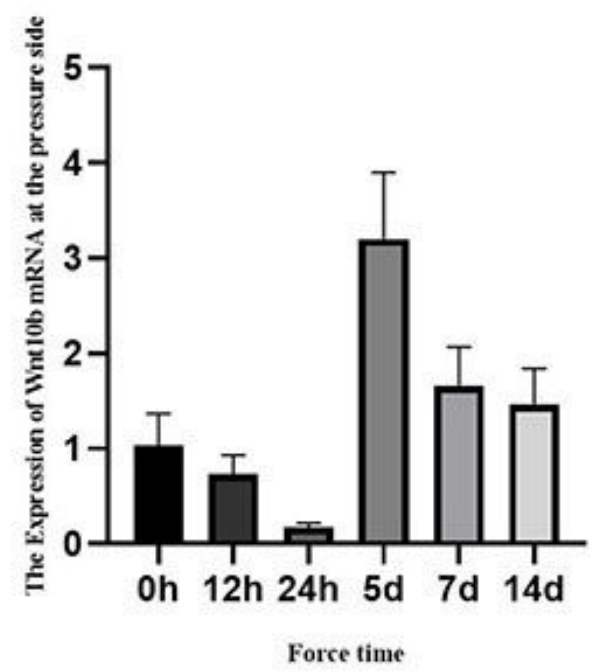

\section{Figure 2}

The expression of Wnt10b mRNA at the different period. The expression was inhabited initially. Over the next 24 hours, the expression level gradually decreased. It peaked on day 5 , then decreased, and by day 14 , returned to normal levels. 


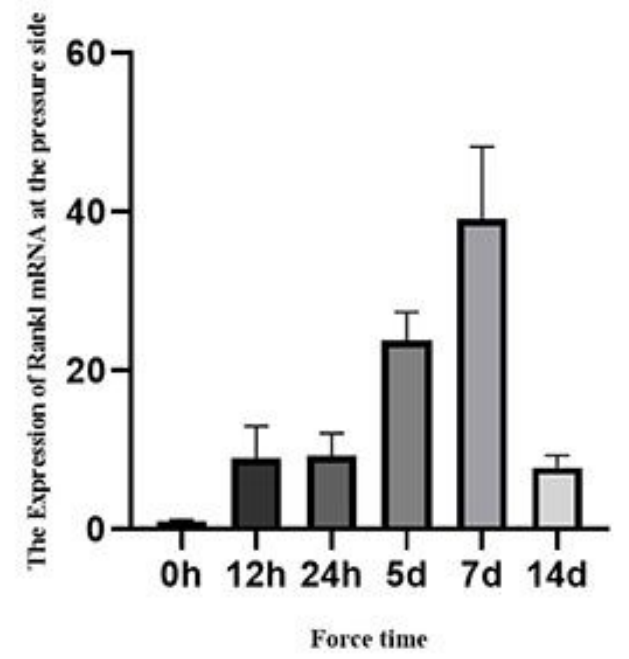

Figure 3

The expression of Rankl mRNA at the different period. The expression level of Rankl mRNA gradually increased with the extension of the loading time $(P<0.05)$, reached the peak on day 7 , and decreased to the normal level after 14 days. 


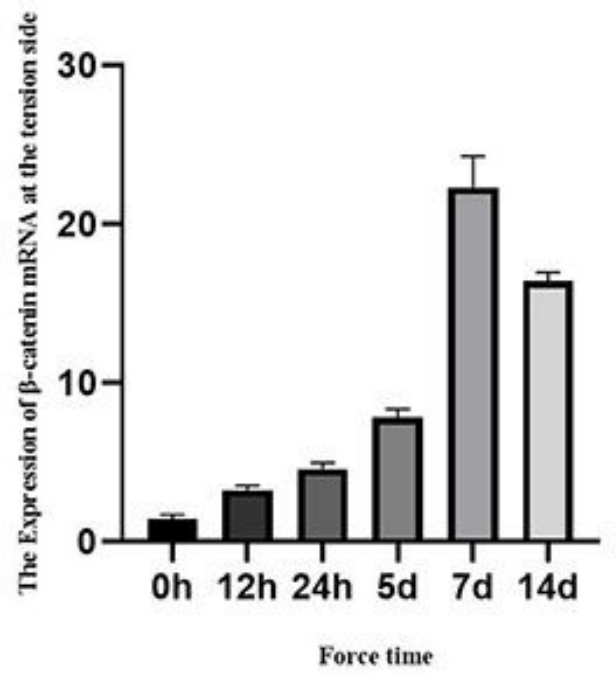

Figure 4

The expression of $\beta$-catenin mRNA at the different period. The expression increased gradually after force loading, and it peaked on day 7 , decreased at day 14 . 


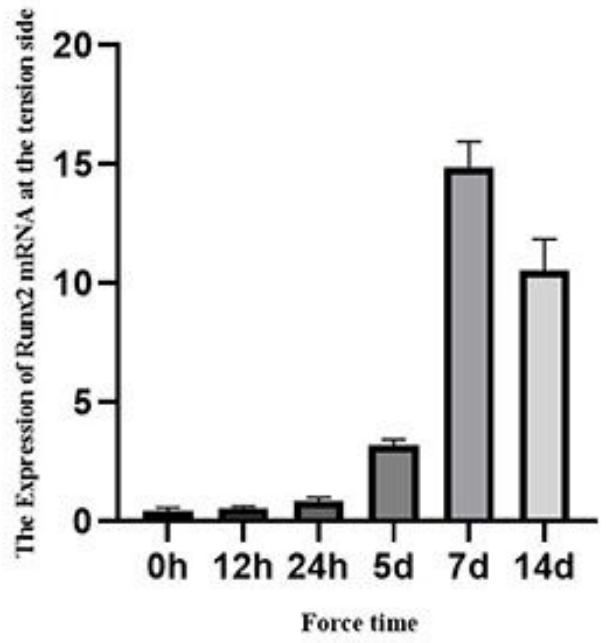

Figure 5

The expression of RunX2 mRNA at the different period. The expression level of Runx2 mRNA increased after applying force. It showed an upward trend with the extension of the loading time, which increased slowly at the beginning, reached the highest level on day 7 , and decreased after day 14. 